\title{
Activation of Protein C In Vivo
}

\author{
Philip C. Comp, Rene M. Jacocks, Gary L. Ferrell, and C. T. Esmon, \\ Departments of Medicine and Pathology, University of Oklahoma Health \\ Sciences Center Oklahoma City, Oklahoma 73190
}

A B S T R A C T An endothelial cell-associated cofactor that greatly enhances the rate of protein $\mathrm{C}$ activation by thrombin has recently been described. The observation that the cofactor binds thrombin with unusually high affinity $\left(K_{\mathrm{d}}=0.5 \mathrm{nM}\right)$ suggested that low level thrombin infusion into dogs might lead to the selective activation of protein $\mathrm{C}$.

Infusion of thrombin $(1 \mathrm{U} / \mathrm{min}$ per $\mathrm{kg}$ body wt) into the jugular vein of dogs leads to the formation of a systemic anticoagulant activity within $5 \mathrm{~min}$ of starting the infusion. The plasma has a prolonged partial thromboplastin time and Factor $\mathrm{X}_{\mathrm{a}}$ clotting time, but there is no change in the thrombin clotting time. The systemic anticoagulant activity is identified as activated protein $C$ for the following reasons: $(a)$ anti-canine activated protein C IgG antibodies inhibit the anticoagulant activity; $(b)$ the anticoagulant activity can be partially purified from the plasma of dogs infused with thrombin by barium citrate adsorption; $(c)$ the anticoagulant has chromatographic properties on QAE Sephadex indistinguishable from those of activated protein $C$, and $(d)$ the rate at which this anticoagulant is inhibited in citrated canine plasma is identical to that of canine activated protein $\mathrm{C}$. The in vivo activation of protein $C$ appears to be receptor mediated since it occurs at low thrombin concentration and since it can be progressively inhibited by simultaneous infusion of diisopropylphospho-thrombin with thrombin. The activation of protein $\mathrm{C}$ at low levels of thrombin is selective, since neither the platelet count nor the Factor $V$ levels are altered. Thrombin infusion leads to an elevation in circulating plasminogen activator levels. This appears to be mediated through the activation of protein $\mathrm{C}$ since coinfusion of diisopropylphospho-thrombin with thrombin inhibits the increase in plasminogen activator levels. Pretreatment of dogs with dicumarol blocks both the formation of anticoagulant activity and the rise in plasminogen activator. When the dicumarol-treated dogs are supplemented with isolated protein $\mathrm{C}$ and thrombin is in-

Address reprint requests to Dr. Philip C. Comp.

Received for publication 15 January 1982 and in revised form 19 March 1982. fused, the anticoagulant activity again appears and the circulating levels of plasminogen activator are again elevated. These studies illustrate that low levels of thrombin in vivo can activate protein $\mathrm{C}$, which in turn can inhibit blood coagulation and initiate fibrinolysis by elevating circulating plasminogen activator levels.

\section{INTRODUCTION}

Protein $\mathrm{C}$ is a vitamin $\mathrm{K}$-dependent plasma protein (1). The activated form of the protein, protein $\mathrm{C}_{\mathrm{a}}$, exhibits a potent $(2,3)$ and highly specific anticoagulant effect expressed through the selective inactivation of clotting Factors $V(4,5)$ and VIII $(5,6)$. The activated forms of these clotting factors are especially susceptible to inactivation by protein $\mathrm{C}_{\mathrm{a}}(6-8)$. Phospholipid and $\mathrm{Ca}^{2+}$ accelerate the inactivation of Factor $\mathrm{V}_{\mathrm{a}}$ and VIII $I_{a}$ by protein $C_{a}(4-9)$. Protein $C_{a}$ also generates fibrinolytic activity in blood both in vitro (10-12) and in vivo (13-14). The in vivo effects are mediated, at least in part, by increased levels of circulating plasminogen activator (14). Thus, the properties of activated protein $C$ suggest an important role for protein $\mathrm{C}$ in the regulation of both clot formation and clot lysis.

Recent studies have implicated protein $\mathrm{C}$ in human disease. Marlar and Griffin (15) have shown that patients lacking an inhibitor to activated protein $\mathrm{C}$ exhibit simultaneous Factor $\mathrm{V}$ and Factor VIII deficiency. A family has now been described with recurrent thrombosis and low levels of protein C antigen (16). Both of these studies further support the hypothesis that protein $\mathrm{C}$ plays a central role in control of clot formation.

Expression of either the anticoagulant $(5,7,8)$ or the fibrinolytic activity (14) of protein $\mathrm{C}$ requires the activation of protein $\mathrm{C}$. Little or no protein $\mathrm{C}$ is activated during blood clotting (17) and depletion of protein $\mathrm{C}$ has no effect on in vitro clotting assays (18). Direct activation of protein $\mathrm{C}$ by thrombin occurs, but the rate of activation is too slow to be physiologically significant $(17,19,20)$. An endothelial cell-associated cofactor, which binds thrombin with high affinity and enhances protein $C$ activation at least 20,000 -fold, has 
been identified $(21,22)$ and isolated (23). The existence of a high affinity receptor for thrombin that accelerates protein $\mathrm{C}$ activation provides a plausible mechanism for activation of protein $C$ in vivo. We have now demonstrated that low level thrombin infusion leads to the selective activation of protein $\mathrm{C}$ in vivo.

\section{METHODS}

Reagents. Bovine blood was the generous gift of the Cornett Packing Company, Oklahoma City, OK. Reagents were purchased from sources previously recorded (14); all were of the highest grade commercially available.

Protein and thrombin preparation. Bovine and canine thrombin were isolated following activation of the purified prothrombin with purified Factor $X_{\mathrm{a}}(24)$, Factor $\mathrm{V}_{\mathrm{a}}(25)$, phospholipid, and $\mathrm{Ca}^{2+}(24)$. For some experiments thrombin was inactivated with $1 \mathrm{mM}$ diisopropylfluorophosphate, dialyzed to remove excess reagent, and used within $48 \mathrm{~h}$.

Protein $C$ preparation. Bovine protein $\mathrm{C}$ and activated protein $\mathrm{C}$ were purified as described previously (26). Canine protein $C$ and activated protein $C$ were purified using the methods described for the isolation of the bovine proteins (26).

Preparation of canine prothrombin complex. To prepare the canine prothrombin complex, pooled citrated canine plasma containing $2 \mathrm{mM}$ benzamidine was used and the prothrombin complex was partially purified by barium citrate adsorption, sodium citrate wash, and EDTA elution (27). The partially purified complex was treated with diisopropylfluorophosphate ( $2 \mathrm{mM}$ final concentration) and dialyzed extensively against $20 \mathrm{mM}$ Tris buffer, $\mathrm{pH} 7.4$, containing $150 \mathrm{mM} \mathrm{NaCl}$. The prothrombin complex was then frozen at $-80^{\circ} \mathrm{C}$ and used within 1 wk

Iodination of protein $C_{a}$. Protein $\mathrm{C}_{\mathrm{a}}$ was labeled with [ ${ }^{125}$ I] iodine by the method of Bolton and Hunter (28) using ( $\mathrm{N}$-succinimidyl 3-(4-hydroxy, 5-[125I] iodophenyl) propionate) (Amersham Corp., Arlington Heights, IL). Specific radioactivity was $\sim 9,800 \mathrm{cpm} / \mu \mathrm{g}$ protein.

Preparation of antibodies. Goat IgG directed against diisopropylfluorophosphate-inactivated canine protein $C_{a}$ was prepared. $10 \mu \mathrm{l}(300 \mu \mathrm{g})$ partially purified IgG were capable of neutralizing $50 \%$ of the anticoagulant activity of $10 \mu \mathrm{g}$ canine protein $\mathrm{C}_{\mathrm{a}}$ added to $1 \mathrm{ml}$ citrated canine plasma after 1 -min incubation at $37^{\circ} \mathrm{C}$. IgG directed against diisopropylfluorophosphate-inactivated bovine protein $\mathrm{C}_{a}$ was prepared in a similar manner.

Assay of activated protein $C$. The Factor $\mathrm{X}_{\mathrm{a}}$ one-stage clotting time was performed as described previously (7) and used to detect protein $\mathrm{C}_{\mathrm{a}}$. The concentration of Factor $\mathrm{X}_{\mathrm{a}}$ was adjusted to give a clotting time of $30 \mathrm{~s}$ in the control plasma $(\sim 6 \mathrm{ng} / \mathrm{ml})$. The level of circulating activated protein $C$ was estimated by reference to a standard curve, which related the prolongation of the Factor $\mathrm{X}_{\mathrm{a}}$ one-stage clotting time to the concentration of added, purified activated protein C (Fig. 1). Protein C was assayed in partially purified samples by activation of the protein $\mathrm{C}$ with thrombin followed by selectively inactivating the thrombin with excess antithrombin III (21). The activated protein $\mathrm{C}$ was then detected using the clotting assay described above.

Levels of circulating lysine-adsorbable plasminogen activator were measured as described previously (29).

Factor $\mathrm{V}$ was assayed as previously described (25).

Animal studies. Mongrel dogs weighing between 10 and $25 \mathrm{~kg}$ were used. The dogs were anesthetized with intra-

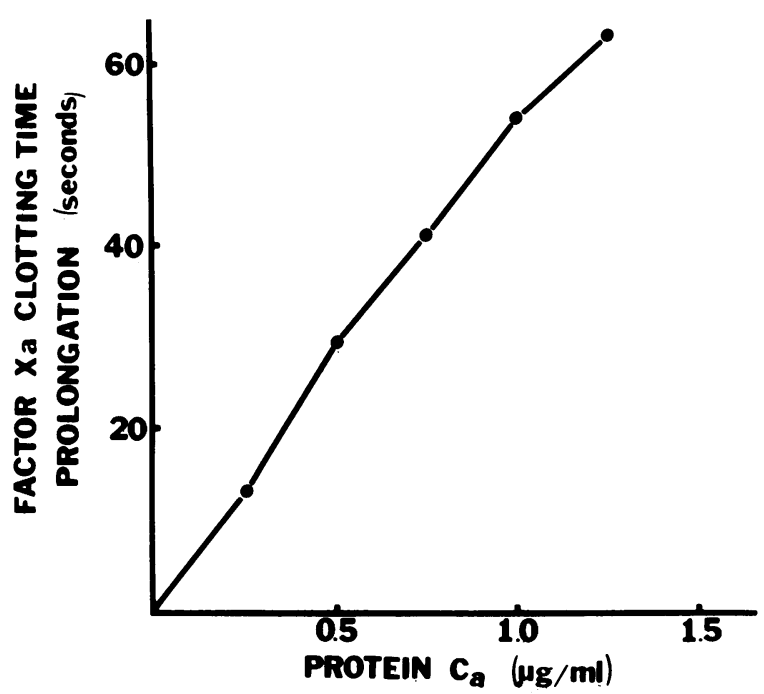

FIGURE 1 Anticoagulant activity of purified canine activated protein $C$. Canine plasma was supplemented to the levels shown by the addition of $5 \mu \mathrm{l}$ of the appropriate concentration of canine activated protein $\mathrm{C}$. This was followed by the sequential addition of $0.1 \mathrm{ml}$ each of cephalin $(50$ $\mu \mathrm{g} / \mathrm{ml}$ ), $0.025 \mathrm{M} \mathrm{CaCl}_{2}$, and Factor $\mathrm{X}_{\mathrm{a}}$. Base-line clotting activities were adjusted to $30 \mathrm{~s}$.

venous sodium nembutol (Abbott Diagnostics, Diagnostic Products, North Chicago, IL). Blood samples were withdrawn from the jugular vein as described (14). Thrombin was infused using a Harvard Pump (Harvard Apparatus Co., S. Natick, MA) through a 2 in. 18-gauge intravenous catheter (Becton, Dickinson \& Co., Rutherford, NJ) inserted into the opposite jugular vein. For coagulation studies blood was anticoagulated with $1 \mathrm{ml} 3.8 \%$ sodium citrate, $\mathrm{pH} 5.5$, per 9 $\mathrm{ml}$ of blood and immediately centrifuged in a Beckman microfuge (Beckman Instruments, Inc., Spinco Div., Palo Alto, CA) for $2 \mathrm{~min}$. All blood and plasma was kept at $4^{\circ} \mathrm{C}$ in plastic tubes before the assay.

Dogs made deficient in vitamin K-dependent plasma proteins were given daily doses of $20 \mathrm{mg}$ dicumarol (Sigma Chemical Co., St. Louis, MO) per kg body wt for $5 \mathrm{~d}$.

The recovery of protein $\mathrm{C}_{\mathrm{a}}$ from dog plasma was performed as outlined above with the following changes: $(a)$ the blood was collected in $10 \mathrm{mM}$ benzamidine, and $5 \mathrm{mM}$ benzamidine was added to the wash and EDTA elution steps. All steps were carried out at $4^{\circ} \mathrm{C}$. The prothrombin complex fractions were dialyzed against 5 liters $5 \mathrm{mM}$ imidazole buffer, $\mathrm{pH} 6.0$, containing $150 \mathrm{mM} \mathrm{NaCl}$, for $18 \mathrm{~h}$ at $4^{\circ} \mathrm{C}$ before chromatography on QAE-Sephadex Q50-120. No diisopropylfluorophosphate was used.

The levels of protein $\mathrm{C}_{\mathrm{a}}$ generated in vivo during thrombin infusion were determined by reference to a standard curve constructed by adding purified canine protein $\mathrm{C}_{\mathrm{a}}$ to normal dog plasma. Under the conditions used, the addition of 0.5 $\mu \mathrm{g}$ canine protein $\mathrm{C} / \mathrm{ml}$ gave a 30 -s prolongation of the $\mathrm{Fac}-$ tor $\mathrm{X}_{\mathrm{a}}$ clotting time. For diisopropylphospho (DIP) ${ }^{1}$-thrombin infusion experiments, the percentage of anticoagulant activity was calculated by dividing the level of protein $\mathrm{C}_{\mathrm{a}}$ generated during DIP-thrombin/thrombin infusion by the level generated during the infusion of thrombin alone.

\footnotetext{
${ }^{1}$ Abbreviation used in this paper: DIP-thrombin; diisopropylphospho-thrombin.
} 


\section{RESULTS}

Formation of activated protein $C$ in vivo. Thrombin was infused at a rate of $1 \mathrm{U} / \mathrm{kg}$ body wt per min (Fig. 2). A marked prolongation of the Factor $\mathrm{X}_{\mathrm{a}}$ onestage clotting time occurred following initiation of the thrombin infusion. When the thrombin was stopped, the prolonged clotting times returned to the base line.

Coagulation studies were initiated to determine if the prolonged clotting times were in response to formation of activated protein $\mathrm{C}$ (Fig. 3). Thrombin infusion at these levels did not influence the thrombin time suggesting that the anticoagulant activity was expressed at the level of prothrombin activation. The possibility that the plasma anticoagulant was activated protein $\mathrm{C}$ was examined using antibodies directed against canine protein $C$. When canine plasma obtained during thrombin infusion was preincubated with antibodies against canine protein $\mathrm{C}$, the prolongation of the Factor $\mathrm{X}_{\mathrm{a}}$ clotting time was corrected.

To further document that protein $\mathrm{C}_{\mathrm{a}}$ was being formed during the thrombin infusion, partial chromatographic characterization of the anticoagulant was undertaken. Anticoagulant activity was recovered from a barium citrate eluate of plasma obtained following thrombin infusion (Methods). When the barium citrate eluate was chromatographed on QAE-Sephadex, the anticoagulant activity was detected in the trailing shoulder of the prothrombin peak at the position where protein C elutes (Fig. 4). Protein $\mathrm{C}_{\mathrm{a}}$ activity

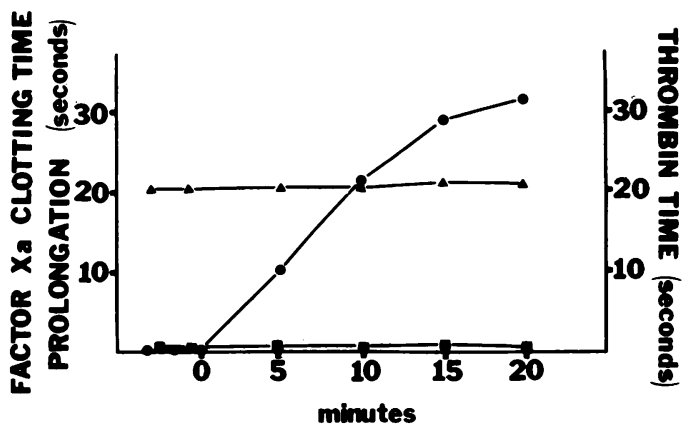

Figure 3 Effect of thrombin infusion on clotting times. A $10-\mathrm{kg}$ dog was infused with $10 \mathrm{U}$ bovine thrombin/min starting at time 0 and continuing for $20 \mathrm{~min}$. Samples of plasma were obtained at the times indicated and Factor $\mathrm{X}_{\mathrm{a}}$ clotting times $(\bullet)$ and thrombin clotting times $(\Delta)$ determined. The Factor $\mathrm{X}_{\mathrm{a}}$ clotting time of plasma samples preincubated with antibodies directed against canine protein $C$ were also determined (ם).

was present in the eluate of the postinfusion plasma, but not in the eluate originating from the prethrombin infusion plasma.

One unusual characteristic of protein $\mathrm{C}_{\mathrm{a}}$ is that the inhibition of the enzyme in plasma is unusually slow and dependent on a unique plasma protease inhibitor (15). To characterize the anticoagulant activity further, the rate of inactivation of purified activated protein $\mathrm{C}$ in canine plasma was compared with the rate of disappearance of the anticoagulant activity formed

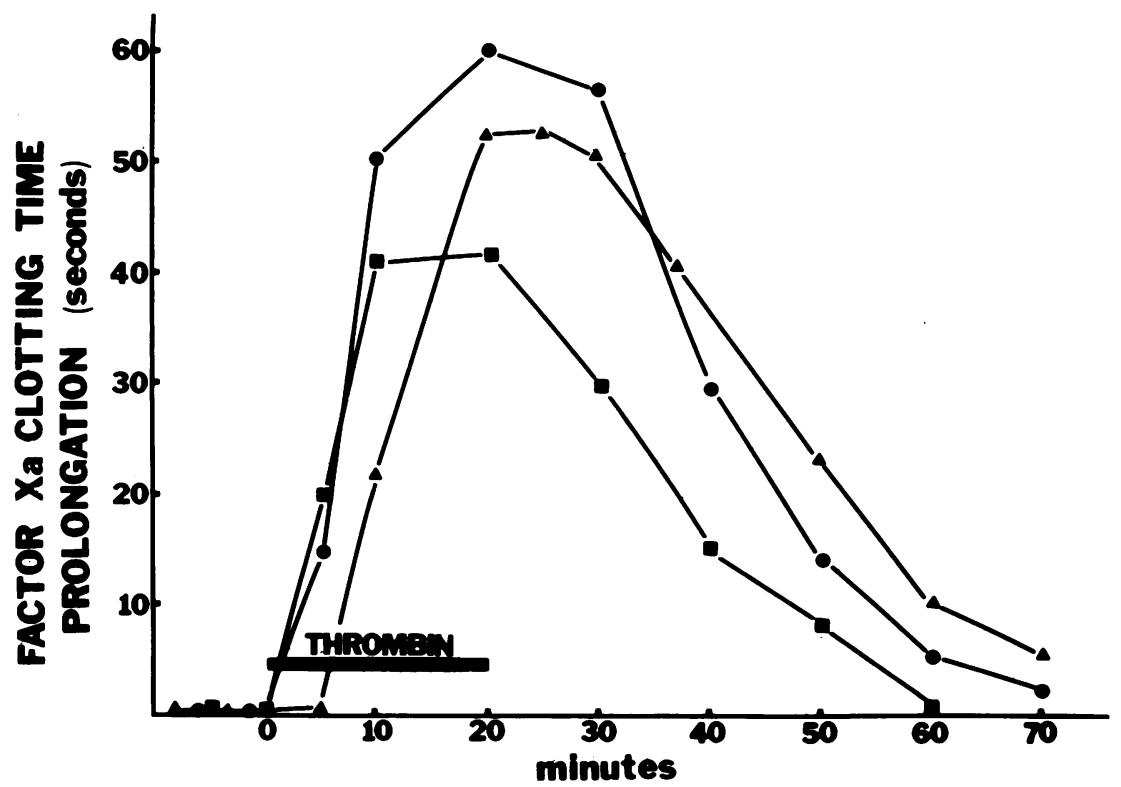

Figure 2 Thrombin infusion into dogs. Thrombin was infused into three anesthetized dogs through the jugular vein at a rate of $1 \mathrm{U} / \mathrm{kg}$ body wt per min over a 20 -min period. Prolongation of the Factor $X_{a}$ clotting time was monitored. Similar results were observed in eight other animals. 


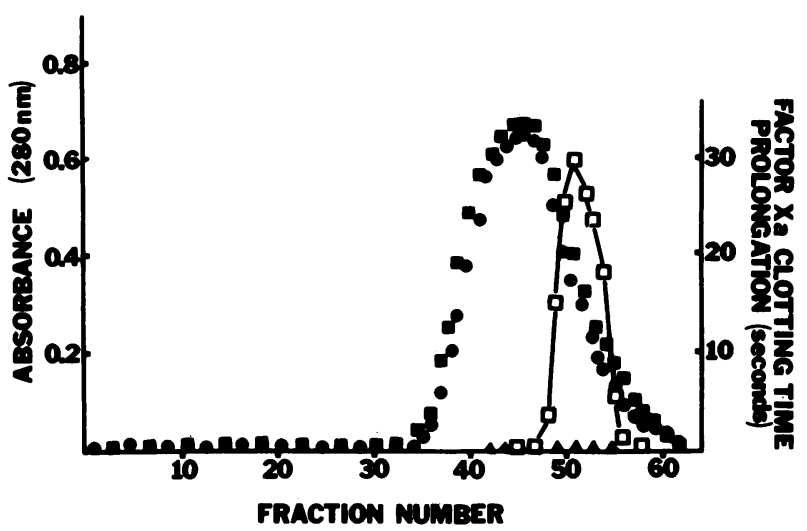

Figure 4 Recovery of protein $\mathrm{C}_{\mathrm{a}}$ from canine plasma. A 13.5-kg dog was infused with $270 \mathrm{U}$ bovine thrombin over a 20 -min period. $20 \mathrm{ml}$ of citrated plasma was obtained before and immediately after thrombin infusion. The vitamin $\mathrm{K}$-dependent plasma proteins were prepared from each sample as described in Methods. These proteins were then chromatographed on $0.9 \times 4-\mathrm{cm}$ QAE Sephadex Q50 columns in $5 \mathrm{mM}$ imidazole buffer, $\mathrm{pH} 6.0$, with a linear gradient of 0.2-0.5 M NaCl. Each gradient chamber contained $15 \mathrm{ml}$ buffer; $0.6 \mathrm{ml}$ fractions were collected. Optical density of fractions made from prethrombin infusion plasma (0) and postthrombin infusion plasma ( $\square$ ) are superimposed. The protein $\mathrm{C}_{\mathrm{a}}$ activity in the fractions from prethrombin infusion $(\Delta)$ and the postthrombin infusion ( $\square$ ) samples were monitored by prolongation of the Factor $X_{a}$ clotting time. The columns were washed with 5-column vol of the lead buffer before starting the gradient at fraction 10. Protein $\mathrm{C}$ activity was detected in fractions 50-52 of both columns after treatment of the fractions with $2 \mathrm{mM}$ diisopropylfluorophosphate followed by dialysis against $2 \mathrm{mM}$ Tris buffer, pH 7.4, containing $150 \mathrm{mM} \mathrm{NaCl}$. The recovery of activated protein $\mathrm{C}$ was $\sim 32 \%$.

in vivo (Fig. 5). The concentration of canine activated protein $\mathrm{C}$ was adjusted to give the same anticoagulant response as that obtained in plasma from a dog infused with thrombin. The rate of disappearance of the anticoagulant formed in vivo was indistinguishable from that of purifed activated protein C. Inhibition of both activities was temperature dependent.

Thrombin catalyzes many reactions other than the activation of protein C. To characterize the anticoagulant response more completely, the influence of thrombin infusion on Factor $\mathrm{V}$ levels, platelet number, and plasminogen activator levels was studied (Fig. 6). Thrombin was infused over $55 \mathrm{~min}$. The Factor $\mathrm{X}_{\mathrm{a}}$ clotting time prolonged reflecting the activation of protein $C$. There was no significant drop in the platelet count suggesting that the plasma levels of thrombin during the infusion were not sufficient to activate a significant number of platelets. Similarily, there was no drop in Factor $\mathrm{V}$ levels. However, an increase in the level of circulating plasminogen activator was observed during thrombin infusion. This result was con-

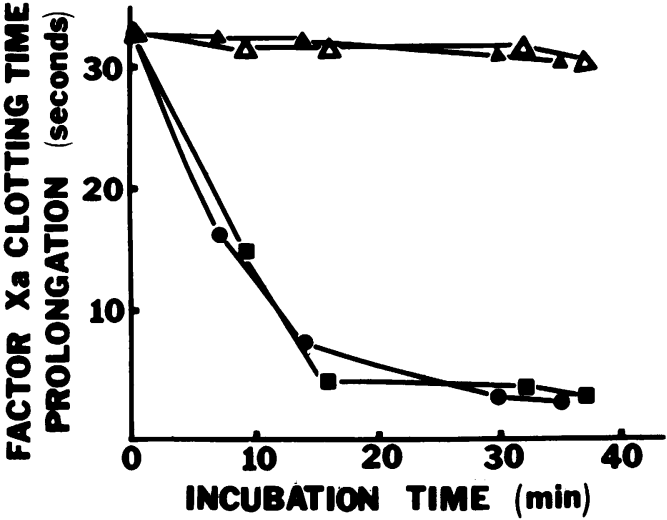

Figure 5 Correction of prolonged clotting times with incubation. Serial Factor $X_{a}$ clotting times were determined in plasma obtained from a dog infused with thrombin, as the plasma was incubated at $37^{\circ}(\bullet)$ or $4^{\circ} \mathrm{C}(\Delta)$. The initial prolongation of the Factor $\mathrm{X}_{\mathrm{a}}$ clotting times was $33 \mathrm{~s}$. Samples of protein $\mathrm{C}_{\mathrm{a}}$ supplemented normal canine plasma were also incubated at $37^{\circ}(\square)$ and $4^{\circ} \mathrm{C}(\Delta)$.

sistent with our previous observation (14) that levels of plasminogen activator rise following intravenous injection of protein $\mathrm{C}_{\mathrm{a}}$ into dogs.

The infusion of thrombin at this level had no effect on blood pressure, pulse rate, or body temperature. Animals had no evidence of bleeding during or following thrombin infusion. Autopsy of one animal immediately following thrombin infusion showed no evidence of fibrin deposition in brain, heart, lungs, liver, or kidneys.

Clearance of activated protein $C$. Since protein $\mathrm{C}_{\mathrm{a}}$ anticoagulant activity following thrombin infusion could be detected systemically, it appeared that the protein was cleared slowly from the circulation. To estimate the clearance rate of protein $C_{a}$, the disappearance of the anticoagulant activity and of ${ }^{125} \mathrm{I}$-protein $\mathrm{C}_{\mathrm{a}}$ was followed (Fig. 7). The labeled protein was cleared at the same rate as the anticoagulant activity. The clearance rate of the purified protein was similar to the time course of disappearance of the anticoagulant activity following cessation of the thrombin infusion (Fig. 2).

Inhibition of protein $C$ activation by DIP-thrombin. The activation of protein $\mathrm{C}$ by a complex between thrombin and the endothelial cell cofactor can be inhibited in a dose-dependent fashion by diisopropylfluorophosphate-inhibited thrombin (DIP-thrombin) $(21,22)$. If the activation of protein $C$ in vivo was catalyzed by a similar thrombin-cofactor complex, then it follows that coinfusion of increasing levels of DIP-thrombin should progressively block protein $\mathrm{C}$ activation. Progressive inhibition of protein $\mathrm{C}$ activation was observed as the ratio of DIP-thrombin/ thrombin was increased (Fig. 8). At ratios of 60 and 


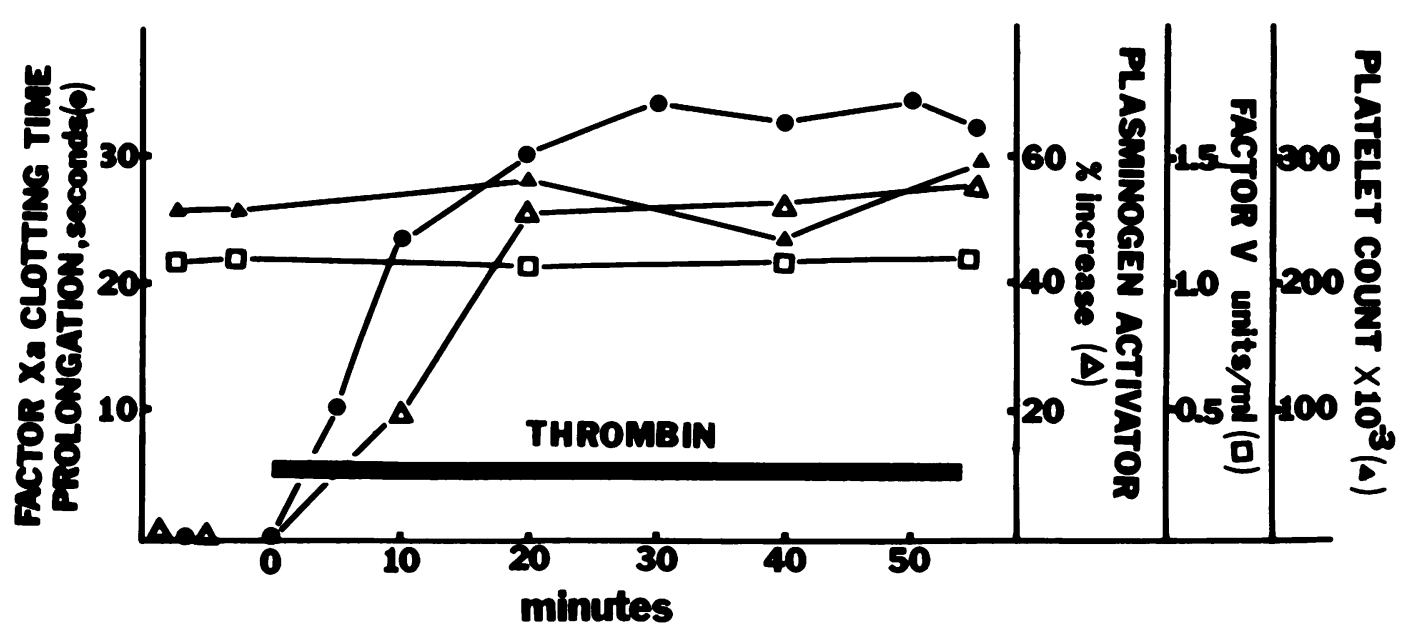

FIGURE 6 Changes in blood parameters during thrombin infusion. Thrombin was infused into a $13.2-\mathrm{kg}$ dog over a $40-\mathrm{min}$ period starting at time 0 at a rate of $1 \mathrm{U}$ thrombin $/ \mathrm{kg}$ per min. Plasminogen activator levels, Factor $\mathrm{V}$ levels, and platelet counts were determined and protein $\mathrm{C}_{\mathrm{a}}$ generation was measured.

100 to 1 there was no activation of protein $\mathrm{C}$ during thrombin infusion. This demonstrated that a cofactor for thrombin was involved in protein $\mathrm{C}$ activation in vivo.

Effect of anticoagulants on protein $C$ activation. Oral dicumarol is known to lower the levels of the functional vitamin $\mathrm{K}$-dependent clotting proteins. We expected that the levels of protein $C$ would also be lowered and that the generation of anticoagulant activity due to protein $\mathrm{C}_{\mathrm{a}}$ would be inhibited. To test this possibility a series of dogs were anticoagulated with dicumarol (Fig. 9). Anticoagulation with dicumarol blocked the generation of functionally active

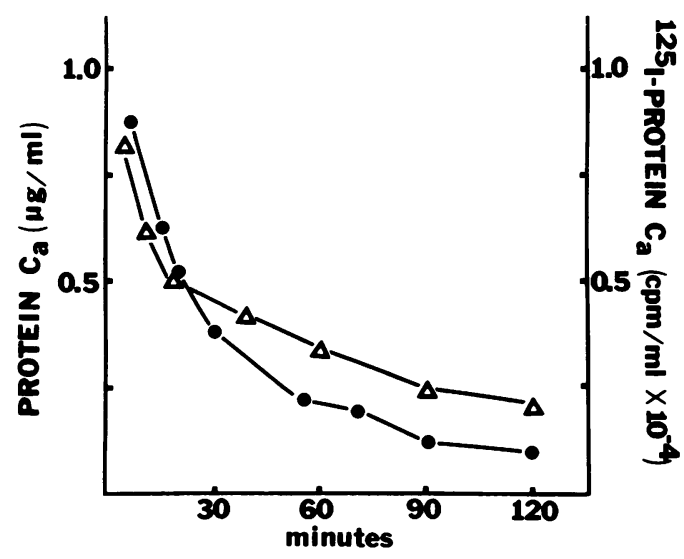

FIgURE 7 Disappearance of ${ }^{125} \mathrm{I}$-protein $\mathrm{C}$ and anticoagulant activity in vivo. A bolus injection of $1 \mathrm{mg}$ of ${ }^{125} \mathrm{I}$-protein $\mathrm{C}_{\mathrm{a}}$ was given at $\mathrm{T}=0$ to a $10.7-\mathrm{kg}$ dog and samples of plasma were assayed for protein $C_{a}$ by Factor $X_{a}$ one-stage assay $(\odot)$ and determination of ${ }^{125} \mathrm{I}$-protein $\mathrm{C}_{\mathrm{a}}$ levels $(\Delta)$ made. protein $\mathrm{C}_{\mathrm{a}}$ during thrombin infusion (middle panel). Supplementation of these animals with the vitamin Kdependent plasma proteins (including protein $\mathrm{C}$ ) restored the response to thrombin infusion. We also wished to determine if protein $\mathrm{C}$ alone was sufficient to restore the response to thrombin or whether other vitamin $\mathrm{K}$-dependent proteins, such as protein $\mathrm{S}$, were

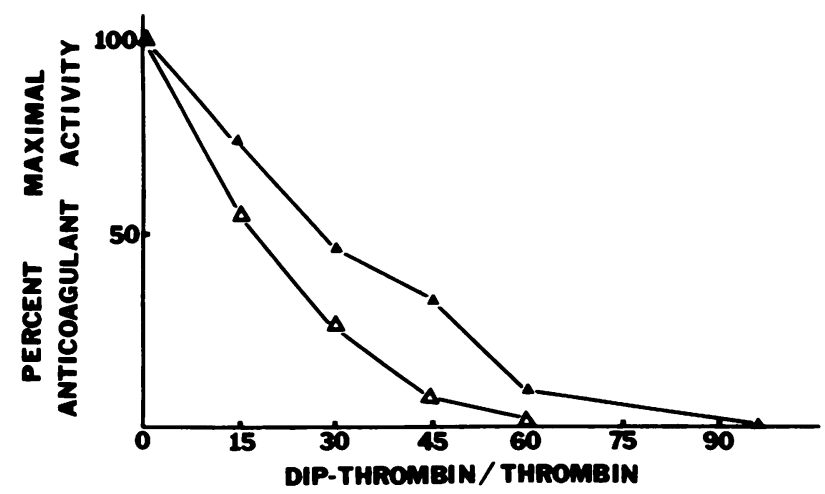

FIGURE 8 Effect of simultaneous thrombin and DIP-thrombin infusion on in vivo protein $\mathrm{C}_{\mathrm{a}}$ generation. Two dogs were infused with $1.0 \mathrm{U}$ thrombin $/ \mathrm{kg}$ per min and the prolongation of Factor $X_{\mathrm{a}}$ clotting measured at 20 min after starting the thrombin infusion. $2 \mathrm{~d}$ later, the animals were infused with DIP-thrombin/thrombin at a 15:1 ratio and the anticoagulant response measured. The ratio of DIP-thrombin/ thrombin was increased at 2-d intervals. The anticoagulant activity observed at $20 \mathrm{~min}$ was expressed as a percentage of the activity seen in the initial thrombin-only infusion. In the experiment shown, a $9.2-\mathrm{kg}(\Delta)$ and a $13.2-\mathrm{kg}(\Delta)$ dog were used. Two other animals gave similar results. The response of the animals to thrombin infusion returned to normal within $24 \mathrm{~h}$ of coinfusion of thrombin and DIP-thrombin. 


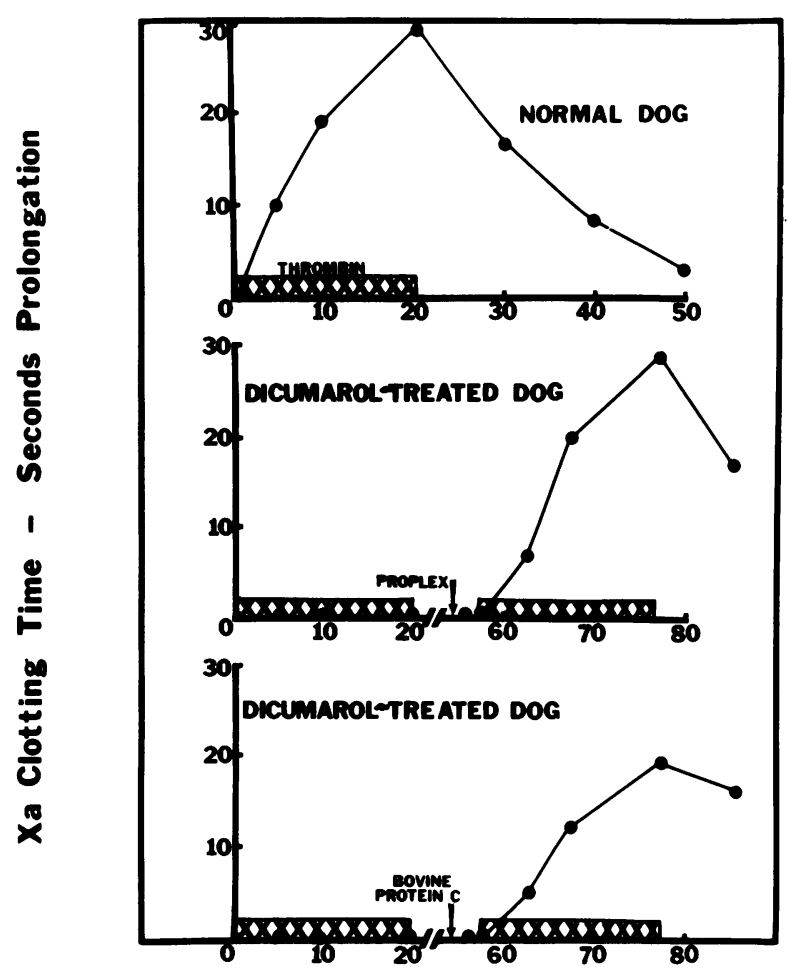

Minutes

Figure 9 Effect of dicumarol administration on in vivo protein $\mathrm{C}$ generation. (Top panel). Thrombin $1.0 \mathrm{U} / \mathrm{kg}$ per min was administered to a normal dog over a $20-\mathrm{min}$ period and protein $C_{a}$ generation measured. The same animal was then anticoagulated with dicumarol and, when Factor X levels were $<0.05 \mathrm{U} / \mathrm{ml}$ plasma, the thrombin infusion was repeated, (middle panel). This infusion was followed $55 \mathrm{~min}$ later by intravenous administration of a sufficient amount of canine prothrombin complex to restore Factor $\mathrm{X}$ levels to $1 \mathrm{U} / \mathrm{ml}$. The thrombin infusion was then repeated. $10 \mathrm{~d}$ later, the animal was again anticoagulated (bottom panel) and the thrombin infusion repeated. $55 \mathrm{~min}$ later, bovine protein $\mathrm{C}$ was administered sufficient to give plasma levels of $5 \mu \mathrm{g} / \mathrm{ml}$. The thrombin infusion was then repeated. Similar results were obtained in two other animals.

needed. Supplementation with protein $\mathrm{C}$ alone was sufficient to restore the response to thrombin infusion (bottom panel).

Since relatively low levels of thrombin are required to activate protein $C$ in vivo we expected that heparin would block the activation of protein $\mathrm{C}$. We found that simultaneous infusion of heparin at levels as low as $0.05 \mathrm{U} / \mathrm{kg}$ per min were sufficient to block protein $\mathrm{C}$ activation, (data not shown).

The relationship between thrombin-induced protein $C$ activation and the elevation of plasminogen activator levels. In Fig. 6 it is apparent that thrombin infusion led to increases in the level of circulating plasminogen activator. In 10 dogs infused with thrombin for $20 \mathrm{~min}$ as described in Fig. 2, the plasminogen activator levels increased $55 \%$ over the basal level (range 44-66\%). Since the activation of protein $\mathrm{C}$ can be inhibited by either coumarin anticoagulants or DIPthrombin, it is possible to correlate the rise in plasminogen activator with the formation of activated protein $\mathrm{C}$ under several conditions. At ratios of DIPthrombin to thrombin that blocked protein $\mathrm{C}$ activation, no increase in the circulating plasminogen activator levels was observed (i.e., in three dogs the change in the plasminogen activator ranged from $-5 \%$ to $+4 \%$ of the basal level). When the vitamin K-dependent plasma protein levels were decreased enough to block the response to thrombin, no increase in plasminogen activator levels was detected (i.e., in three dogs the change in plasminogen activator ranged from $-3 \%$ to $+4 \%$ of the basal level). When these dogs were supplemented with either protein $\mathrm{C}$ alone or all the vitamin K-dependent proteins, an elevation of the plasminogen activator levels in response to thrombin was again observed. In two dogs supplemented with protein $\mathrm{C}$ as described in Fig. 9, the plasminogen activator level increased $42 \%$ in response to thrombin infusion (range $36-48 \%$ increase over the basal level).

\section{DISCUSSION}

These studies suggest that low levels of thrombin can lead to protein $C$ activation in vivo. Coupled with the findings of others $(15,16,22)$ the observations presented here are compatible with the model illustrated in Fig. 10.

The observation that protein $\mathrm{C}$ is activated before significant Factor $\mathrm{V}$ activation (Fig. 6) is a reversal of the normal substrate preference exhibited by thrombin. In vitro, thrombin activation of Factor $\mathrm{V}$ in plasma is much more rapid than activation of protein $C$ (17). The in vivo results are compatible with the concept that thrombin activation of protein $\mathrm{C}$ is receptor mediated. Receptor involvement is further implicated by the observation that DIP-thrombin blocks the activation of protein C. At present the vascular endothelium is the only known source of such a receptor. The absence of a comparable receptor in blood can be reasonably inferred by the observation that significant protein $\mathrm{C}$ can be isolated from serum (17).

The selective activation of protein $\mathrm{C}$, which we have demonstrated in the dog, is highly dependent on the dose of thrombin administered. The rapid intravenous administration of high doses of thrombin results in the precipitous fall in plasma fibrinogen, Factor $\mathrm{V}$, and platelets. Activation of protein $C$ under such conditions may well occur, but the appearance of fibrin degradation products, fibrin monomer, and decreased fibrinogen levels would make detection of activated protein $\mathrm{C}$ more difficult. 


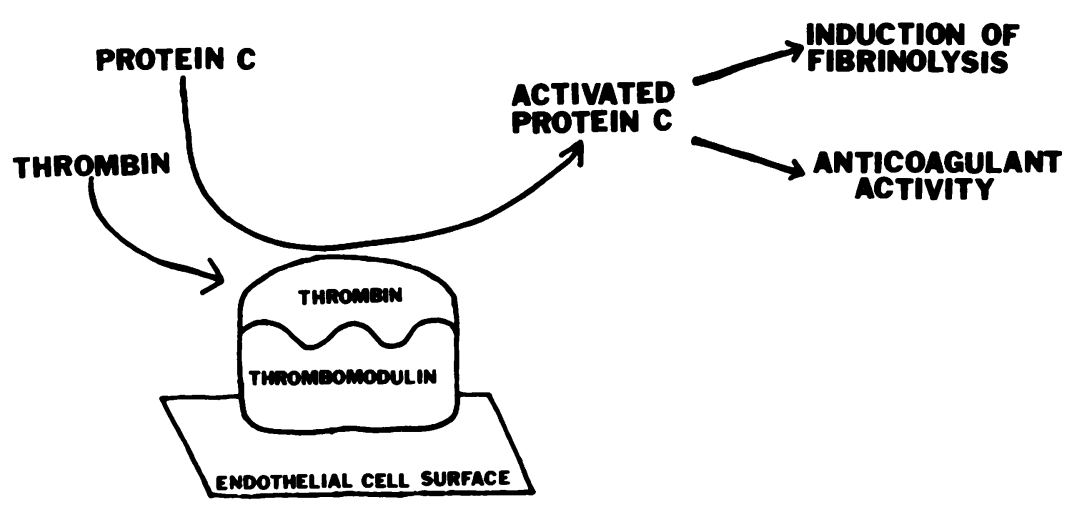

Figure 10 Proposed model of in vivo protein $\mathrm{C}$ activation.

The anticoagulant response observed upon thrombin infusion decays slowly. The time course of disappearance of the anticoagulant activity in vivo closely resembles the time course of disappearance of activated protein $C$. The similarity of these two curves suggest that the slow return to control levels is dependent primarily on the slow inactivation of activated protein C. If the protein $C$ activation complex were exceptionally stable, then the apparent disappearance of the in vivo anticoagulant activity would be much slower than that seen following direct administration of protein $\mathrm{C}_{2}$. Accurate estimation of the stability of the protein $\mathrm{C}$ activation complex in vivo will require additional experiments and new approaches.

The observation that thrombin can elevate plasminogen activator is not new (30). However, the studies described here imply that the elevation of circulating plasminogen activator may be closely coupled and/or dependent on the activation of protein $\mathrm{C}$. Two independent observations support this conclusion. DIPthrombin, which blocks protein $\mathrm{C}$ activation in vivo, also blocks elevation of plasminogen activator. Since DIP-thrombin does not block direct activation of substrates such as fibrinogen or Factor $\mathrm{V},{ }^{2}$ it appears that the increase in plasminogen activator is either dependent on protein $\mathrm{C}$ activation or on some other receptormediated process involving thrombin. Support for the concept that protein $\mathrm{C}$ is involved comes from the observation that dicumarol blocks the increase in plasminogen activator levels. Supplementation with isolated protein $\mathrm{C}$ corrects the inability of the animal to increase plasminogen activator levels in response to thrombin. Thus, elevation of plasminogen activator levels in response to low level thrombin infusion ap-

\footnotetext{
${ }^{2}$ Esmon, C. T., Esmon, N. L., and Harris, K. W. 1982. Complex formation between thrombin and thrombomodulin inhibits both thrombin-catalyzed fibrin formation and Factor $\mathrm{V}$ activation. Submitted for publication.
}

pears to be both receptor mediated and dependent on a normal vitamin $\mathrm{K}$ status. Since activated protein $\mathrm{C}$ can elevate circulating plasminogen activator in the absence of added thrombin (14), it would appear likely that protein $\mathrm{C}$ activation in response to thrombin may be an important link between the coagulation system and the fibrinolytic system.

\section{ACKNOWLEDGMENTS}

We wish to thank Mrs. Barbara Irish for her efforts in preparing this manuscript.

This work was supported by grant HL17812 from the National Heart and Lung Institute.

\section{REFERENCES}

1. Stenflo J. 1976. A new vitamin K-dependent protein: purification from bovine plasma and preliminary characterization. J. Biol. Chem. 251: 355-363.

2. Mammen, E. F., W. R. Thomas., and W. H. Seegers. 1960. Activation of purified prothrombin to autoprothrombin I or autoprothrombin II (platelet cofactor II) or autoprothrombin II-A. Thromb. Diath. Haemorrh. 5: 218-227.

3. Marciniak, E. Coagulation inhibitor elicited by thrombin. 1970. Science. (Wash. DC). 170: 452-453.

4. Kisiel, W., W. M. Canfield, L. H. Ericsson, and E. W. Davie. 1977. Anticoagulant properties of bovine protein C following activation by thrombin. Biochemistry. 16: 5824-5831

5. Marlar, R. A., A. J. Kleiss, and J. H. Griffin. 1980. Anticoagulant action of human protein C. Protides Biol. Fluids Proc. Colloq. 28: 341-345.

6. Vehar, G. A., and E. W. Davie. 1980. Preparation and properties of bovine Factor VIII. Biochemistry. 19: 401410.

7. Walker, F. J., P. W. Sexton, and C. T. Esmon. 1979. The inhibition of blood coagulation by activated protein $\mathrm{C}$ through selective inactivation of activated Factor $\mathrm{V}$. Biochim. Biophys. Acta. 571: 333-342.

8. Canfield, W., M. Neshiem, W. Kisiel, and K. Mann. 1978. Proteolytic inactivation of bovine Factor $V_{a}$ by bovine activated protein C. Circulation. 210 (Suppl. II): $57-58$. 
9. Esmon, C. T., P. Comp, and F. Walker. 1980. Functions for protein C. In Vitamin $\mathrm{K}$ Metabolism and Vitamin K-dependent Proteins. J. W. Suttie, editor. University Park Press, Baltimore, Md. 72-83.

10. Zolton, R. P., and W. H. Seegers. 1973. Autoprothrombin II-A: thrombin removal and mechanism of induction of fibrinolysis. Thromb. Res. 3: 23-33.

11. Comp, P. C., and C. T. Esmon. 1980. Evidence for multiple roles for activated protein $\mathrm{C}$ in fibrinolysis. In The Regulation of Coagulation. K. G. Mann and F. B. Taylor, editors. Elsevier North-Holland, Inc., New York. 583588.

12. Taylor, F. B., C. T. Esmon, R. C. Carroll, and M. L. Lockhart. 1981. Adherent mononuclear cells and activated protein C (APC). Thromb. Hemostasis. 46: 178 (Abstr.).

13. Seegers, W. H., L. E. McCoy, H. D. Groben, N. Sakuragawa, and B. L. Agrawal. 1972. Purification and some properties of autoprothrombin II-A; an anticoagulant perhaps also related to fibrinolysis. Thromb. Res. 1: 443460.

14. Comp, P. C., and C. T. Esmon. 1981. Generation of fibrinolytic activity by infusion of activated protein $\mathrm{C}$ into dogs. J. Clin. Invest. 68: 1221-1228.

15. Marlar, R. A., and J. H. Griffin. 1980. Deficiency of protein $\mathbf{C}$ inhibitor in combined Factor V/VIII deficiency disease. J. Clin. Invest. 66: 1186-1189.

16. Griffin, J. H., B. Evatt, T. S. Zimmerman, A. J. Kleiss, and C. Wideman. 1981. Deficiency of protein C in congenital thrombotic disease. J. Clin. Invest. 68: 13701373.

17. Kisiel, W., L. H. Ericsson, and E. W. Davie. 1976. Proteolytic activation of protein $\mathrm{C}$ from bovine plasma. Biochemistry. 15: 4893-4900.

18. Esmon, C. T., J. Stenflo, J. W. Suttie, and C. M. Jackson. 1976. A new vitamin K-dependent protein. A phospholipid-binding zymogen of a serine esterase. J. Biol. Chem. 251: 3052-3056.

19. Amphlett, G. W., W. Kisiel, and F. J. Castellino. 1981. Interaction of calcium with bovine plasma protein $\mathrm{C}$. Biochemistry. 20: 2156-2161.

20. Esmon, C. T., and W. G. Owen. 1980. Formation and functions of the anticoagulant protein, activated protein
C. In Plasma and Cellular Modulatory Proteins. D. $\mathbf{H}$. Bing and R. A. Rosenbaum, editors. Center for Blood Research, Inc., Boston, Mass. 203-214.

21. Esmon, C. T., and W. G. Owen. 1981. Identification of an endothelial cell cofactor for thrombin-catalyzed activation of protein C. Proc. Natl. Acad. Sci. U.S.A. 78: 2249-2252.

22. Owen, W. G., and C. T. Esmon, 1981. Functional properties of an endothelial cell cofactor for thrombin-catalyzed activation of protein C. J. Biol. Chem. 256: 55325535.

23. Esmon, N. L., W. G. Owen, and C. T. Esmon. 1982. Isolation of a membrane bound cofactor for thrombin catalyzed activation of protein C. J. Biol. Chem. 257: 859-864.

24. Owen, W. G., C. T. Esmon, and C. M. Jackson. 1974. The conversion of prothrombin to thrombin. I. Characterization of the reaction products formed during activation of bovine prothrombin. J. Biol. Chem. 249: 594603.

25. Esmon, C. T. 1979. The subunit structure of thrombinactivated Factor V. J. Biol. Chem. 254: 964-973.

26. Comp, P., and C. T. Esmon. 1979. Activated protein C inhibits platelet prothrombin-converting activity. Blood. 54: 1272-1281.

27. Moore, H. C., S. E. Lux, O. P. Malhotra, S. Bakerman, and J. R. Carter. 1965. Isolation and purification of bovine and canine prothrombin. Biochim. Biophys. Acta. 111: 174-180.

28. Bolton, A. E., and W. M. Hunter. 1973. The labeling of proteins to high specific radioactivities by conjugation to a ${ }^{125}$ I-acylating agent. J. Biochem. (Tokyo). 133: 529539.

29. Comp, P. C., R. M. Jacocks, C. Rubenstein, and R. Radcliffe. 1981. A specific circulating plasminogen activator, or class of activators, is elevated in conditions associated with increased fibrinolytic activity. J. Lab. Clin. Med. 97: 637-649.

30. Landaburu, R. H., E. Giavedoni, E., and R. Santillan. 1968. Thrombin and acetylated thrombin in the activation of fibrinolysis. Can. J. Physiol. Pharmacol. 46: 809-813. 